\title{
KONSEP PEMBUKTIAN TERBALIK SEBAGAI STRATEGI PENCEGAHAN DAN PEMBERANTASAN TINDAK PIDANA PENCUCIAN UANG PADA SEKTOR PASAR MODAL UNTUK SARANA PENDANAAN TERORISME
}

\author{
Lutfi Hafiz Rafsanjani* \\ Universitas Diponegoro \\ *Correspondent Email : luthfihafidzrafsanjani@gmail.com
}

Naskah diterima: 29/10/2021, Revisi: 15/11/2021, Disetujui: 31/12/2021

\begin{abstract}
Abstrak
Sebagai negara yang terletak dalam posisi silang, baik dari aspek kewilayahan maupun sosial politik, memungkinkan Indonesia menjadi tempat persinggahan berkaitan dengan tindak kejahatan. Terorisme dan pencucian uang sebagai bagian dari kejahatan luar biasa turut menjadi benalu yang berpotensi mengancam keselamatan serta keutuhan bangsa. Penyusunan Karya Tulis Ilmiah ini bertujuan untuk menelaah kondisi mengenai tindak pidana pencucian uang pada sektor pasar modal dan keterkaitannya dengan sarana pendanaan terorisme melalui konsep pembuktian terbalik sebagai penyokong upaya pencegahan dan pemberantasan tindak pidana pencucian uang di sektor pasar modal yang diperuntukan sebagai sarana pendanaan terorisme di Indonesia. Penyusunan Karya Tulis Ilmiah ini menggunakan metode penelitian doktrinal. Hasil dari penelitian ini antara lain: a) bahwa tindak pidana pencucian uang yang diperuntukan sebagai sarana pendanaan terorisme telah berkembang pesat baik dari segi corak kejahatan maupun cara yang dilakukan, termasuk saat ini telah merambah ke dalam sektor pasar modal; b) terdapat kesulitan yang dihadapi oleh aparat penegak hukum dalam hal pembuktian atas tindak pidana pencucian uang dan pendanaan terorisme karena ketentuan peraturan perundangundangan yang ada saat ini belum cukup optimal untuk mendukung upaya tersebut. Rekomendasi yang diberikan oleh penulis dari penyusunan karya tulis ilmiah ini antara lain: a) perlu dilakukannya suatu penerapan konsep pembuktian terbalik khususnya yang berkaitan dengan ketentuan kewenangan pemblokiran dan perluasannya dalam hal ketentuan mengenai subjek hukum serta objek pengenaannya; b) guna mengakomodasi penerapan konsep pembuktian terbalik tersebut, maka diperlukan suatu perubahan dan penyesuaian terhadap peraturan perundang-undangan yang berkaitan dengan tindak pidana pencucian uang dan pendanaan terorisme.
\end{abstract}

How to cite:

Rafsanjani, L. (2021). Konsep Pembuktian Terbalik Sebagai Strategi Pencegahan dan Pemberantasan Tindak Pidana Pencucian Uang Pada Sektor Pasar Modal untuk Sarana Pendanaan Terorisme. Ikatan Penulis Mahasiswa Hukum Indonesia Law Journal, 1(2).

Diterbitkan oleh:

Ikatan Penulis Mahasiswa Hukum Indonesia

IPMHI Law Journal

${ }^{\circledR} 2021$ Author 
Kata Kunci : Pasar Modal; Pembuktian Terbalik; Pencucian Uang; Pendanaan Terorisme; Tindak Pidana

\section{PENDAHULUAN}

\section{Latar Belakang}

Terorisme memenjadi salah satu dari sekian tindak pidana yang masuk ke dalam daftar predicate offence ${ }^{l}$ dari tindak pidana pencucian uang sebagaimana yang disebutkan dalam Pasal 2 ayat (1) huruf $n$ dan Pasal 2 ayat (2) Undang-Undang Nomor 8 Tahun 2010 tentang Pencegahan dan Pemberantasan Tindak Pidana Pencucian Uang. Melalui ketentuan undang-undang tersebut, menunjukkan dengan jelas bahwa terorisme merupakan bagian integral yang tidak dapat terpisahkan dari tindak pidana pencucian uang, terutama yang berkaitan dengan harta kekayaan yang secara langsung atau tidak langsung diketahui, patut diduga akan digunakan, dan/atau dipergunakan untuk kegiatan terorisme juga dapat disamakan sebagai bagian dari bentuk tindak pidana pencucian uang. Setidaknya terdapat 417 orang dan 99 entitas (baik berupa organisasi maupun yayasan) yang masuk ke dalam Daftar Terduga Teroris dan Organisasi Teroris (DTTOT), sehingga dari jumlah yang mengkhawatirkan ini membuktikan bahwa Indonesia masuk ke dalam lingkar terorisme, termasuk tindak pidana terorisme dan tindak pidana pendanaan terorisme. ${ }^{2}$ Terorisme tentunya sangat membahayakan dan dapat mengancam keselamatan bangsa, hal ini karena sifat dari tindak pidana terorisme dan tindak pidana lain yang berkaitan dengan terorisme bersifat transnasional dan terorganisasi (transnational and organized crimes) ${ }^{3}$, sehingga dalam upaya pencegahan dan pemberantasan tindak pidana terorisme tidak dapat dilakukan hanya secara parsial, akan tetapi harus dilakukan secara holistik dan komprehensif dari hulu hingga hilir.

Pendanaan merupakan "aliran darah" dari tindak pidana terorisme yang harus diputus untuk menghentikan mata rantai terorisme. ${ }^{4}$ Secara global, telah terdapat berbagai ketentuan yang dijadikan standar bagi negara-negara di dunia dalam melawan tindak pidana pencucian uang dan pendanaan terorisme, di antaranya yaitu yang dikeluarkan oleh Financial Action Task Force (FATF) dengan program Anti Pencucian Uang atau Anti Money Laundering (APU/AML) dan Pemberantasan Pendanaan Terorisme atau Counter Terrorism Financing (PPT/CTF).

Pencucian uang yang dilakukan khususnya pada harta kekayaan yang diketahui serta patut diduga berasal dari dan/atau akan dimanfaatkan baik secara langsung maupun tidak langsung sebagai penyokong pendanaan terorisme. Pasar modal dengan berbagai instrumennya potensial dijadikan sebagai sarana pencucian uang, khususnya yang berkaitan dengan pendanaan terorisme (di samping PJK lainnya seperti sektor perbankan maupun nonperbankan), karena mengingat

\footnotetext{
${ }^{1}$ Pasal 2 ayat (1) UU Nomor 8 Tahun 2010 tentang Pencegahan dan Pemberantasan Tindak Pidana Pencucian Uang.

${ }^{2}$ Daftar Terduga Teroris dan Organisasi Teroris Nomor: DTTOT/P-7a/149/II/RES.6.1./2021 yang ditandatangani oleh Kepala Detasemen Khusus 88 Anti Teror (KADENSUS 88 AT) Marthinus Hukom.

${ }^{3}$ Penjelasan atas Undang-Undang Nomor 5 Tahun 2018 tentang Perubahan Atas Undang-Undang Nomor 15 Tahun 2003 tentang Penetapan Peraturan Pemerintah Pengganti Undang-Undang Nomor 1 Tahun 2002 tentang Pemberantasan Tindak Pidana Terorisme

${ }^{4}$ Max Fredrik Leatemia, (2019). Kerja Sama Pemberantasan Pendanaan Terorisme di Asia Tenggara Departemen Ilmu Hubungan Internasional, Paradigma POLISTAAT: Jurnal Ilmu Sosial dan Ilmu Politik, Vol. 21, No. 1, p. 13.
} 
kapitalisasi pasar modal yang tinggi ${ }^{5}$ Berdasarkan data transaksi keuangan mencurigakan yang dikonfirmasi oleh Pusat Pelaporan dan Analisis Transaksi Keuangan (PPATK) menunjukkan bahwa setidaknya terdapat peningkatan dari 10 Laporan Transaksi Keuangan Mencurigakan (LTKM) menjadi 219 atau melonjak sebesar 20,9 persen pada LKTM di sektor pasar modal selama semester pertama 2020, jika dibandingkan dengan periode yang sama pada $2019 .{ }^{6}$ Dari data tersebut menunjukkan bahwa sektor pasar modal dapat menjadi sasaran empuk bagi pelaku tindak pidana pencucian uang dan pendanaan terorisme. Sangat dimungkinkan kedepannya akan berkembang teknik yang lebih canggih melalui pemanfaatan sarana lain dengan teknologi tinggi untuk mengamuflase pentransferan dan aliran dana yang diketahui atau patut diduga akan dimanfaatkan untuk menyokong tindak kejahatan lainnya.

Landasan yang mendasari upaya pencegahan dan pemberantasan tindak pidana pencucian uang dan pendanaan terorisme di Indonesia saat ini terdapat pada Undang-Undang Nomor 8 Tahun 2010 tentang Pencegahan dan Pemberantasan Tindak Pidana Pencucian Uang dan Undang-Undang Nomor 9 Tahun 2013 tentang Pencegahan dan Pemberantasan Tindak Pidana Pendanaan Terorisme, serta peraturan perundang-undangan lain yang berada di bawahnya yang secara teknis mengatur mengenai pelaksanaan kedua undang-undang tersebut. Selain itu, didukung juga oleh Undang-Undang Nomor 6 Tahun 2006 tentang Pengesahan International Convention for the Suppression of the Financing of Terrorism 1999 (Konvensi Internasional Pemberantasan Pendanaan Terorisme 1999) sebagai komitmen dan bentuk pengikatan diri Indonesia pada konvensi internasional tersebut.

Saat ini sudah diatur berbagai kebijakan dalam rangka mencegah serta memberantas tindak pidana pencucian uang dan pendanaan terorisme, khususnya berkaitan dengan proses penyidikan, penuntutan, hingga putusan pengadilan, serta upaya lain seperti pemblokiran, penyitaan, dan perampasan harta kekayaan yang diketahui atau patut diduga diperoleh dari hasil kejahatan. Namun, dalam keberjalanannya, aparat penyidik ${ }^{7}$ seringkali masih dihadapkan pada permasalahan berkenaan dengan sulitnya pembuktian unsur mens rea (unsur subjektif) maupun unsur objektif dalam tindak pidana pencucian uang, karena pendekatan yang digunakan selama ini cenderung berorientasi pada pengejaran aliran dana (follow the money).

\footnotetext{
Indonesia Stock Exchange, Press Release PR Nomor 066/BEI.SPR/09-2021, https://www.idx.co.id/berita/press-release-detail/?emitenCode $=1577$ (diakses pada 26 September 2021).

${ }^{6}$ Dhiany Nadya Utami, "PPATK Sebut Transaksi Mencurigakan di Pasar Modal Melonjak, BEI Angkat Bicara", Bisnis.com, https://market.bisnis.com/read/20200923/7/1295774/ppatk-sebuttransaksi-mencurigakan-di-pasar-modal-melonjak-bei-angkat-bicara (diakses pada 26 September 2021).

${ }^{7}$ Putusan Mahkamah Agung Nomor 15/PUU-XIX/2021 tentang Permohonan Pengujian UndangUndang Nomor 8 Tahun 2010 tentang Pencegahan dan Pemberantasan Tindak Pidana Pencucian Uang terhadap Undang-Undang Dasar Negara Republik Indonesia Tahun 1945.
} 
Sebenarnya, terdapat upaya lain yang dapat diterapkan untuk memudahkan proses penyidikan yang dibebankan kepada aparat penyidik selain berfokus pada pengejaran aliran dana, di antaranya yaitu melalui upaya pembalikan beban pembuktian bagi setiap orang atau korporasi yang diketahui atau patut diduga melakukan tindak pidana pencucian uang dan pendanaan terorisme untuk dengan sendirinya membuktikan bahwa harta kekayaan yang dimilikinya tersebut diperoleh secara sah atau bukan berasal dari tindak pidana.

Oleh karena itu, terdapat urgensi untuk menerapkan suatu konsep pembuktian terbalik bagi setiap orang dan korporasi yang diketahui atau patut diduga akan atau telah melakukan tindak pidana pencucian uang di sektor pasar modal dengan peruntukan sebagai sarana pendanaan terorisme di Indonesia, agar dapat mempermudah aparat penyidik dalam melakukan upaya penyidikan dan pengumpulan alat bukti yang berkaitan dengan tindak pidana tersebut. Berdasarkan pemaparan di atas, maka penulis menggagas penyusunan suatu karya tulis ilmiah dengan judul: "Konsep Pembuktian Terbalik sebagai Strategi Pencegahan dan Pemberantasan Tindak Pidana Pencucian Uang pada Sektor Pasar Modal untuk Sarana Pendanaan Terorisme".

\section{Perumusan Masalah}

1. Bagaimana kondisi mengenai pencegahan dan pemberantasan tindak pidana pencucian uang pada sektor pasar modal dengan keterkaitannya sebagai sarana pendanaan terorisme di Indonesia saat ini?

2. Bagaimana konsep pembuktian terbalik dapat dijadikan sebagai strategi dalam upaya pencegahan dan pemberantasan tindak pidana pencucian uang pada sektor pasar modal yang diperuntukan sebagai sarana pendanaan terorisme di Indonesia?

\section{METODE}

Penulis menggunakan metode penelitian hukum doktrinal penyusunan karya tulis ilmiah ini. Penelitian hukum dokrinal (docrinal legal research) atau penelitian hukum normatif dapat diartikan sebagai suatu metode penelitian di bidang keilmuan hukum yang kegiatan pengkajiannya dilakukan atau ditujukan melalui proses inventarisasi, interpretasi, sistematisasi, dan evaluasiseluruh hukum positif (peraturan perundang-undangan tertulis yang berlaku) dengan menggunakan sarana konsep, klasifikasi, teori, dan metode yang dibangun serta dikembangkan secara khusus untuk mempersiapkan upaya penemuan pemecahan yuridis berkenaan dengan masalah hukum yang mungkin terjadi di masyarakat. ${ }^{8}$

Teknik yang digunakan untuk mengumpulkan data dan informasi sekunder yang menjadi bahan rujukan dalam penelitian hukum doktrinal ini bertumpu pada penelusuran melalui kajian kepustakaan (library research), studi dokumen (document study), dan studi arsip (file or record study) terhadap bahan hukum primer, bahan hukum sekunder, dan bahan hukum tersier atau nonhukum sebagai pisau analisis. ${ }^{9}$ Sedangkan, teknik pengolahan dan analisis data dan informasi yang digunakan dalam penyusunan karya tulis ilmiah ini di antaranya dilakukan dengan tahapan : perumusan masalah; inventarisasi, identifikasi, klasifikasi, dan sistematisasi hukum positif dan bahan pustaka lainnya; penentuan metode

\footnotetext{
${ }^{8}$ Bambang Sunggono, (1997). Metodologi Penelitian Hukum, Jakarta: Raja Grafindo Persada, p 42.

${ }^{9}$ Peter Mahmud Marzuki. 2005. Penelitian Hukum: Edisi Revisi, Jakarta: Kencana Prenada Media Group, p. 181-184. Lihat juga pada Amiruddin dan Zainal Asikin. 2006. Pengantar Metode Penelitian Hukum. Jakarta: PT RajaGrafindo Persada, p. 118.
} 
penelitian dan kerangka berpikir; serta melakukan analisis secara kualitatif dengan cara mengolah data dan melakukan interpretasi terhadap data yang telah diolah. ${ }^{10}$

\section{HASIL PENELITIAN DAN PEMBAHASAN}

\section{KONDISI MENGENAI PENCEGAHAN DAN PEMBERANTASAN TINDAK PIDANA PENCUCIAN UANG PADA SEKTOR PASAR MODAL DENGAN KETERKAITANNYA SEBAGAI SARANA PENDANAAN TERORISME DI INDONESIA SAAT INI}

Untuk menyembunyikan atau menyamarkan harta kekayaan yang berasal dari hasil tindak pidana, terdapat beberapa cara yang dapat digunakan, salah satunya yaitu dengan melakukan pencucian uang. Tidak terkecuali pendanaan terorisme, di mana tindak pidana tersebut juga sangat berkaitan erat dengan tindak pidana pencucian uang, terutama yang berkaitan dengan harta kekayaan yang secara langsung atau tidak langsung diketahui, patut diduga akan digunakan, dan/atau dipergunakan untuk kegiatan terorisme juga dapat disamakan sebagai bagian dari bentuk tindak pidana pencucian uang.

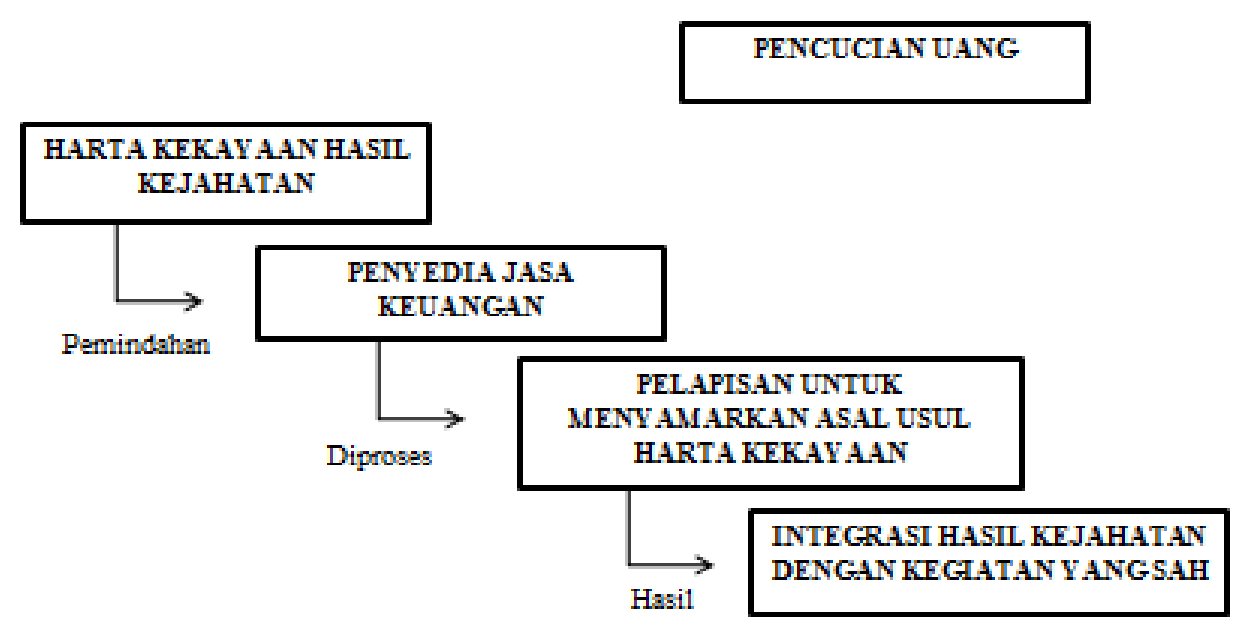

\section{Gambar 1. Alur Kejahatan Pencucian Uang}

Beberapa modus dalam tindak pidana pendanaan terorisme dapat diketahui berdasarkan pada tahapan-tahapan dengan masing-masing sumber, bentuk, dan peruntukanya, di antaranya itu dimulai dari tahap pengumpulan dana (collecting), tahap pemindahan pemindahan dana (moving), dan tahap penggunaan dana (using). Pada tahap pengumpulan dana, umumnya berasal dari beberapa sumber seperti dalam bentuk donasi, pendanaan sendiri (selffunding), dan pendanaan melalui media sosial. Kemudian, pada tahap pemindahan dana dapat dilakukan dalam berbagai bentuk, di antaranya itu dengan pembawaan uang secara tunai, penggunaan Layanan Penyelenggara Transfer Dana (PTD) berizin bukan bank, serta penggunaan layanan perbankan dan nonperbankan. Setelah melalui beberapa tahapan, tujuan akhir dari pendanaan terorisme tentunya bermuara pada penggunaan dana itu sendiri, di antaranya yaitu digunakan untuk pembelian senjata dan bahan peledak, mobilitas anggota teror dan kebutuhan perjalanan warga negara Indonesia yang menjadi pejuang teroris asing (foreign terrorist fighter),

${ }^{10}$ Suratman dan H. Philip Dilah. 2013. Metode Penelitian Hukum. Bandung: Penerbit Alfabeta, p 82-87. 
pelatihan perang, santunan keluarga pelaku teror, dan pengelolaan jaringan teror. ${ }^{11}$

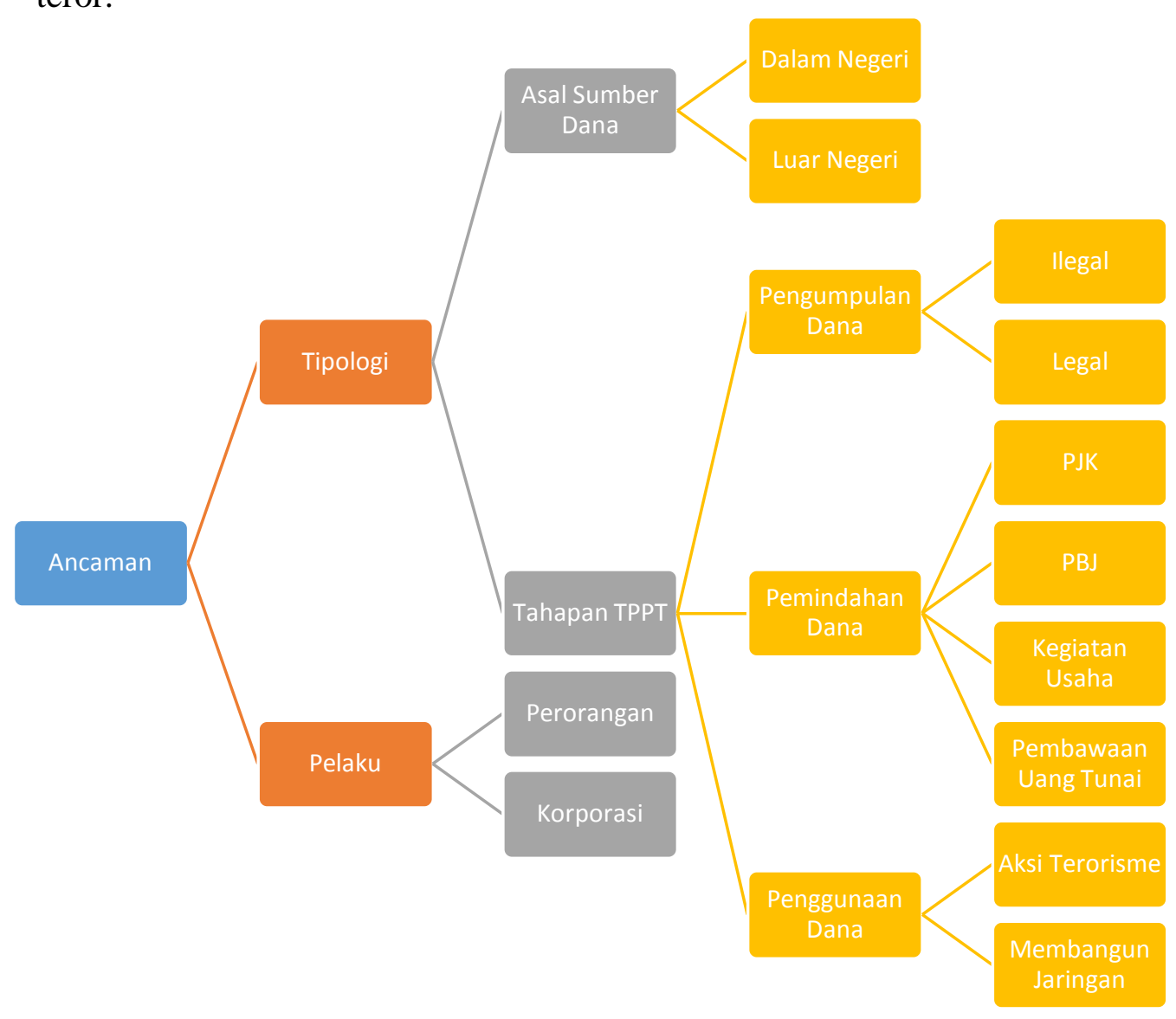

Gambar 2. Konsepsi mengenai Alur Pendanaan Terorisme

Tidak hanya pada sektor perbankan, PJK di sektor pasar modal juga sangat rentan terhadap peluangnya untuk digunakan sebagai sarana pencucian uang dan pendanaan terorisme. PJK di sektor pasar modal dimungkinkan dapat menjadi pintu masuk bagi harta kekayaan yang dihasilkan dari suatu tindak pidana untuk masuk ke dalam sistem keuangan yang selanjutnya dapat dimanfaatkan untuk pemenuhan kepentingan pelaku kejahatan. ${ }^{12}$ Misalnya, untuk pelaku pendanaan terorisme, harta kekayaan tersebut dapat ditarik kembali sebagai harta kekayaan yang seolah-olah sah dan tidak lagi dapat dilacak asal-usulnya, yang kemudiandapat digunakan untuk membiayai kegiatan terorisme. Sehingga, diperlukan suatu pendekatan berbasis risiko baik dalam lingkup nasional maupun sektoral agar sektor pasar modal dan sektor PJK lainnya secara responsif dapat menyikapi perkembangan dan perubahan tantangan yang berkaitan dengan upaya pencegahan dan pemberantasan tindak pidana pencucian uang dan pendanaan terorisme.

Semangat pencegahan dan pemberantasan tindak pidana pencucian uang dan tindak pidana pendanaan terorisme saat ini dilandasi oleh kehadiran

\footnotetext{
11 Tim Pelaksana Pengkinian Penilaian Risiko Indonesia Terhadap Tindak Pidana Pendanaan Terorisme. 2015, Pengkinian Penilaian Risiko Indonesia Terhadap Tindak Pidana Pendanaan Terorisme Tahun 2015 (NRA TPPT 2015 UPDATED): Laporan Akhir Mei 2019, Jakarta: Pusat Pelaporan dan Analisis Transaksi Keuangan, 2019), p. 18-30.

12 Konsideran Peraturan Otoritas Jasa Keuangan Nomor 23/POJK.01/2019 tentang Perubahan Atas

Peraturan Otoritas Jasa Keuangan Nomor 12/POJK.01/2017 tentang Penerapan Program Anti Pencucian Uang dan Pencegahan Pendanaan Terorisme di Sektor Jasa Keuangan.
} 
dari Undang-undang Nomor 8 Tahun 2010 tentang Pencegahan dan Pemberantasan Tindak Pidana Pencucian Uang dan Undang-Undang Nomor 9 Tahun 2013 tentang Pencegahan dan Pemberantasan Tindak Pidana Pendanaan Terorisme. Di samping itu, saat ini sudah terdapat pula pemberlakuan beberapa ketentuan pelaksana dari kedua undang-undang tersebut dalam rangka mengoptimalkan pelaksanaan pencegahan, pengawasan, dan penegakan hukum pada TPPU dan TPPT, di antaranya yaitu:

a. Peraturan Pemerintah Nomor 43 Tahun 2015 tentang Pihak Pelapor dalam Pencegahan dan Pemberantasan Tindak Pidana Pencucian Uang;

b. Peraturan Presiden Nomor 18 Tahun 2017 tentang Tata Cara Penerimaan dan Pemberian Sumbangan oleh Organisasi Kemasyarakatan dalam Pencegahan Tindak Pidana Pendanaan Terorisme;

c. Peraturan Otoritas Jasa Keuangan Nomor 22/POJK.04/2014 tentang Prinsip Mengenal Nasabah oleh Penyedia Jasa Keuangan di Pasar Modal;

d. Peraturan Otoritas Jasa Keuangan Nomor 23/POJK.01/2019 tentang Perubahan Atas Peraturan Otoritas Jasa Keuangan Nomor 12/POJK.01/2017 tentang Penerapan Program Anti Pencucian Uang dan Pencegahan Pendanaan Terorisme di Sektor Jasa Keuangan;

e. Peraturan Pusat Pelaporan dan Analisis Transaksi Keuangan Nomor 11 Tahun 2021 tentang Sistem Informasi Terduga Pendanaan Terorisme.

Berkaitan dengan mekanisme pemblokiran misalnya, telah termuat dalam Pasal 22 sampai dengan Pasal 26 Undang-Undang Nomor 9 Tahun 2013 tentang Pencegahan dan Pemberantasan Tindak Pidana Pendanaan Terorisme. Akan tetapi, dari pengaturan tersebut menurut penulis masih menyisakan permasalahan, karena sifatnya yang masih membatasi ruang gerak aparat penyidik beserta dengan PJK atau instansi berwenang untuk melakukan pemblokiran terhadap dana yang diketahui atau patut diduga baik secara langsung dan tidak langsung seluruhnya maupun sebagian digunakan atau akan digunakan untuk menyokong tindak pidana terorisme. Hal ini dikarenakan pada ketentuan Pasal 23 ayat (2) Undang-Undang Nomor 9 Tahun 2013 tentang Pencegahan dan Pemberantasan Tindak Pidana Pendanaan Terorisme masih memberikan pembatasan bahwa pemblokiran hanya dapat dilakukan dengan penetapan Pengadilan Negeri Jakarta Pusat. Sehingga, dari ketentuan tersebut berpotensi akan membatasi ruang gerak aparat penyidik untuk berpacu mengumpulkan alat bukti yang berkaitan dengan tindak pidana pendanaan terorisme agar tidak begitu saja hilang atau berpindah tempat. Mengacu pada Resolusi Dewan Keamanan PBB Nomor 1373, prosedur pelacakan, pembekuan, penyitaan aset-aset teroris dalam proses penyidikan kasus terorisme maupun dalam proses lainnya dalam kasus pendanaan terorisme dapat dilakukan terhadap harta kekayaan dengan prinsip without delay and without prior notice to targets (tanpa ditunda dan tanpa pemberitahuan terlebih dahulu) kepada setiap orang yang diduga melakukan atau akan melakukan pendanaan terorisme tersebut, sekalipun tiada penuntutan. ${ }^{13}$

\section{PENERAPAN KONSEP PEMBUKTIAN TERBALIK SEBAGAI STRATEGI DALAM UPAYA PENCEGAHAN DAN PEMBERANTASAN TINDAK PIDANA PENCUCIAN UANG PADA}

\footnotetext{
${ }^{13}$ Badan Pembinaan Hukum Nasional. 2012. Naskah Akademik RUU Pemberantasan Pendanaan Terorisme, Jakarta: Kementerian Hukum dan Hak Asasi Manusia Republik Indonesia, p. 30.
} 


\section{SEKTOR PASAR MODAL YANG DIPERUNTUKAN SEBAGAI SARANA PENDANAAN TERORISME DI INDONESIA}

Pembalikan beban pembuktian atau biasa dikenal sebagai pembuktian terbalik umumnya dikenal dalam suatu ketentuan undang-undang yang mengatur mengenai pemberantasan tindak pidana korupsi. Dalam Pasal 37 Undang-Undang Nomor 31 Tahun 1999 tentang Pemberantasan Tindak Pidana Korupsi diatur bahwa pembuktian atas suatu tindak pidana dapat dibebankan bukan kepada jaksa, melainkan kepada terdakwa. Pada ketentuan tersebut, terdakwa dapat membuktikan bahwa ia tidak bersalah melakukan suatu tindak pidana. Apabila ternyata kemudian terdakwa tidak mampu membuktikan, maka keterangannya dapat memperkuat alat bukti yang sudah ada bahwa ia telah melakukan suatu tindak pidana.

Munculnya konsep pembuktian terbalik didasarkan pada di lapangan mengenai sulitnya untuk melakukan pembuktian berkenaan dengan unsur subjektif (mens rea) dari TPPU dan TPPT, di mana jaksa harus membuktikan bahwa pelaku (terduga) mempunyai niat batin (yang kedudukannya terletak satu tingkat di bawah dolus eventualis dan satu tingkat di atas culpa lata) untuk melakukan suatu tindak pidana. ${ }^{14}$ Unsur "patut diduga" sebagaimana yang menjadi mens rea dari suatu delik pencucian uang dan pendanaan terorisme dapat diartikan sama dengan hal pembuktian menurut Pasal 480 Kitab Undang-undang Hukum Pidana (KUHP), yaitu berkaitan dengan teori pro parte dolus, pro parte culpa. Berkenaan dengan teori pro parte dolus, pro parte culpa tersebut dalam perumusannya memuat unsur kesengajaan dan kealpaan yang sekaligus ditujukan pada elemen tertentu. Hal ini berarti bahwa pelaku tidak perlu benar-benar mengetahui terlebih dahulu untuk kemudian dilakukan suatu pembuktian bahwa harta kekayaan atau barang yang di bawah kekuasaannya atau diterima dari orang lain tersebut berasal dari kejahatan. ${ }^{15}$

Melihat adanya kesulitan aparat penegak hukum dalam hal melakukan penyidikan serta pembuktian atas tindak pidana pencucian uang dan pendanaan terorisme sekaligus potensi dari adanya konsep pembuktian terbalik tersebut, maka sudah sepatutnya untuk dilakukan suatu penerapan metode pembuktian terbalik dan perluasannya dalam hal ketentuan mengenai subjek hukum serta objek pengenaan dari metode pembuktian terbalik ini. Tidak hanya kepada terdakwa dengan harta kekayaannya saja, akan tetapi dalam penerapannya terhadap setiap orang maupun korporasi yang diketahui atau patut diduga akan atau telah melakukan tindak pidana pencucian uang di sektor pasar modal dengan peruntukan sebagai sarana pendanaan terorisme di Indonesia dengan mengkombinasikan antara ketentuan mengenai pemblokiran atas aksesibilitas harta kekayaan atau dana dengan konsep pembuktian terbalik. Selain itu, dapat pula dilakukan suatu pemblokiran atas harta kekayaan atau dana yang diketahui serta patut diduga berasal dari dan/atau akan dimanfaatkan baik secara langsung maupun tidak langsung

\footnotetext{
${ }^{14}$ Yenti Garnasih. 2017. Penegakan Hukum Anti Pencucian Uang dan Permasalahannya, Jakarta: PT RajaGrafindo Persada, p 221-222.

${ }^{15}$ Nyoman Serikat Putra Jaya dan Komariah E. S. dalam Mahkamah Konstitusi Republik Indonesia. 2015. "Acara Mendengarkan Keterangan Ahli yang diajukan Mahkamah (VI) Senin, 19 Oktober 2015", Risalah Sidang Perkara Nomor 90/PUU-XIII/2015 perihal Pengujian Undang-Undang Nomor 8 Tahun 2010 tentang Pencegahan dan Pemberantasan Tindak Pidana Pencucian Uang terhadap Undang-Undang Dasar Negara Republik Indonesia Tahun 1945, (Jakarta: Mahkamah Konstitusi, 2015), p. 5-10.
} 
sebagai penyokong pendanaan terorisme guna melakukan pembuktian terbalik dengan memanfaatkan serta mengintegrasikan sarana DTOTT dan sistem informasi penunjang lainnya guna memudahkan aparat penyidik untuk melakukan pembuktian atas suatu tindak pidana pencucian uang dan pendanaan terorisme.

Pemberlakuan suatu konsep pembuktian terbalik ini tentunya juga telah dipertimbangkan dengan hal-hal yang berkaitan dengan jaminan atas perlindungan Hak Asasi Manusia (HAM) sebagai hak konstitusional warga negara sebagaimana yang tertuang dalam Undang-Undang Dasar Negara Republik Indonesia Tahun 1945 (UUD NRI Tahun 1945), khususnya berkenaan dengan jaminan kepastian hukum, perlindungan diri dan hak milik pribadi beserta dengan harta benda yang berada di bawah kekuasaan seseorang. Hal ini didasari oleh ketentuan dalam UUD NRI Tahun 1945 bahwa jaminan HAM tersebut tidak ditentukan sebagai suatu hak asasi yang tidak dapat dikurangi dalam keadaan apapun (non-derogable rights $)^{16}$, dan hak asasi yang tidak termasuk dalam klasifikasi sebagai non-derogable rights dapat dilakukan suatu pembatasan yang ditetapkan dengan undang-undang ${ }^{17}$, terlebih lagi bahwa pencucian uang dan terorisme termasuk sebagai suatu kejahatan luar biasa (extraordinary crimes).

Serta, apabila konsep pembuktian terbalik ini dilakukan pertimbangan juga terhadap ketentuan yang berlawanan, seperti contohnya yaitu Pasal 183 Undang-Undang Nomor 8 Tahun 1981 tentang Hukum Acara Pidana, maka seharusnya tidak terdapat pertentangan di antara keduanya karena undangundang mengenai pemberantasan pencucian uang dan pendanaan terorisme bersifat lex specialis derogat legi generali terhadap undang-undang mengenai hukum acara pidana. Sehingga, melalui konsep pembuktian terbalik ini dapat menjadi landasan yuridis bagi aparat penegak hukum untuk dapat memerintahkan PJK untuk melakukan pemblokiran terhadap rekening efek maupun harta kekayaan atau dana setiap orang atau korporasi yang diduga keras berkaitan dengan tindak pidana pencucian uang dan terorisme.

\section{SIMPULAN DAN SARAN}

\section{A. Kesimpulan}

Berdasarkan permasalah diatas dapat disimpulkan bahwa tindak pidana pencucian uang yang diperuntukan sebagai sarana pendanaan terorisme telah berkembang pesat baik dari segi corak kejahatan maupun cara yang dilakukan, termasuk saat ini telah merambah ke dalam sektor pasar modal. Selain itu, terdapat kesulitan yang dihadapi oleh aparat penegak hukum dalam hal pembuktian atas tindak pidana pencucian uang dan pendanaan terorisme karena ketentuan peraturan perundang-undangan yang ada saat ini belum cukup optimal untuk mendukung upaya tersebut.

Adapun rekomendasi yang diberikan oleh penulis dari penyusunan karya tulis ilmiah ini antara lain: perlu dilakukannya suatu penerapan konsep pembuktian terbalik khususnya yang berkaitan dengan ketentuan kewenangan pemblokiran dan perluasannya dalam hal ketentuan mengenai subjek hukum serta objek pengenaannya. Disisi lain, guna mengakomodasi penerapan konsep pembuktian terbalik tersebut, maka diperlukan suatu

${ }^{16}$ Lihat pada Pasal 28I ayat (1) Undang-Undang Dasar Negara Republik Indonesia Tahun 1945.

${ }^{17}$ Lihat pada Pasal 28J ayat (2) Undang-Undang Dasar Negara Republik Indonesia Tahun 1945. 
perubahan dan penyesuaian terhadap peraturan perundang-undangan yang berkaitan dengan tindak pidana pencucian uang dan pendanaan terorisme

\section{DAFTAR PUSTAKA}

Buku

Amin, R. (2020).Hukum Pembuktian dalam Perkara Pidana dan Perdata. Yogyakarta: Deepublish Publisher.

Amiruddin \& Zainal Asikin.(2006). Pengantar Metode Penelitian Hukum. Jakarta: PT RajaGrafindo Persada.

Garnasih, Y. (2017).Penegakan Hukum Anti Pencucian Uang dan Permasalahannya. Jakarta: PT RajaGrafindo Persada.

Hakim, L. (2020).Asas-asas Hukum Pidana: Buku Ajar bagi Mahasiswa. Yogyakarta: Penerbit DeepublishInciardi, J.A. (1987).Criminal Justice. New York: Harcourt Brace Jovanovich Publisher.

Ishaq. (2017).Metode Penelitian Hukum. Bandung: Penerbit Alfabeta.

Kiser, S. (2005).Financing Terror: An Analysis and Simulation for Affecting Al Qaeda's Financial Infrastructures. California: Pardee Rand Graduate School.

Marzuki, P.M. (2005).Penelitian Hukum: Edisi Revisi. Jakarta: Kencana Prenada Media Group.

Mochtar, A. (2009). Penerapan Pembalikan Beban Pembuktian dalam Pemberantasan Tindak Pidana Korupsi di Indonesia. Jakarta: Sekretariat Jenderal dan Kepaniteraan Mahkamah Konstitusi.

Moeljatno. (2015).Asas-asas Hukum Pidana, cet. IX. Jakarta: Rineka Cipta.

Muhaimin. (2020).Metode Penelitian Hukum. Mataram: Mataram University Press.

Nur, M.T., et.al.(2018). Pembalikan Beban Pembuktian dalam Hukum Pidana Indonesia dan Hukum Pidana Islam. Palopo: Lembaga Penerbit Kampus IAIN Palopo.

Rahmah, M. (2019).Hukum Pasar Modal. Jakarta: Penerbit Kencana Prenadamedia Group.

Rechtschaffen, A.N. (2009).Capital Market, Derivatives and The Law. New York: Oxford University Press, Inc.

Sianturi,S.R. (1986).Asas-Asas Hukum Pidana di Indonesia. Jakarta: Alumni AHAEMPETAHAEM.

Sunggono, B. (1997).Metodologi Penelitian Hukum. Jakarta: RajaGrafindo Persada.

Suratman \& H. Philip Dilah. (2013).Metode Penelitian Hukum. Bandung: Penerbit Alfabeta.

Suriasumantri, J.S. Filsafat Ilmu: Sebuah Pengantar Populer. Jakarta: Pustaka Sinar Harapan.

\section{Jurnal}

Alkostar, A.(2013). "Penerapan Undang-Undang Tindak Pidana Pencucian Uang dalam Hubungannya dengan Predicate Crimes".Masalah-Masalah Hukum, Jilid 42 No. 1.

Garnasih, Y.(2004). "Kriminalisasi Pencucian Uang di Indonesia dan Permasalahan Implementasinya".Media Hukum Vol. 2 No. 10.

Koro, A. (2011). "Pendanaan Terorisme diperoleh dari Tindak Pidana Pencucian Uang (Money Laundering)".Jurnal Hukum dan Pembangunan, Vol. 41, No. 4.

Leatemia, M.F. (2019). "Kerja Sama Pemberantasan Pendanaan Terorisme di Asia Tenggara Departemen Ilmu Hubungan Internasional".Paradigma POLISTAAT: Jurnal Ilmu Sosial dan Ilmu Politik. Vol. 21, No. 1.

Yanuar, M.A. (2019). "Diskursus Antara Kedudukan Delik Pencucian Uang sebagai Independent Crime dengan sebagai Follow Up Crime Pasca Putusan MK Nomor 90/PUU-XIII/2015”.Jurnal Konstitusi, Vol. 16 No. 4. 


\section{Hasil Penelitian dan Risalah}

Badan Pembinaan Hukum Nasional. (2012). Naskah Akademik RUU Pemberantasan Pendanaan Terorisme. (Jakarta: Kementerian Hukum dan Hak Asasi Manusia Republik Indonesia.

Mahkamah Agung Republik Indonesia. (2006).Naskah Akademis Money Laundering. Jakarta: Mahkamah Agung Republik Indonesia.

Mahkamah Konstitusi Republik Indonesia. (2015). “Acara Mendengarkan Keterangan Ahli yang diajukan Mahkamah (VI) Senin, 19 Oktober 2015”. Risalah Sidang Perkara Nomor 90/PUU-XIII/2015 perihal Pengujian Undang-Undang Nomor 8 Tahun 2010 tentang Pencegahan dan Pemberantasan Tindak Pidana Pencucian Uang terhadap Undang-Undang Dasar Negara Republik Indonesia Tahun 1945. Jakarta: Mahkamah Konstitusi.

Tim Pelaksana Pengkinian Penilaian Risiko Indonesia Terhadap Tindak Pidana Pendanaan Terorisme 2015. (2019).Pengkinian Penilaian Risiko Indonesia Terhadap Tindak Pidana Pendanaan Terorisme Tahun 2015 (NRA TPPT 2015 UPDATED): Laporan Akhir Mei 2019. Jakarta, Pusat Pelaporan dan Analisis Transaksi Keuangan.

\section{Internet}

Financial Action Task Force.FATF IX Special Recommendation. https://www.fatfgafi.org/media/fatf/documents/reports/FATF\%20Standards\%20\%20IX\%20Special\%20Recommendations\%20and\%20IN\%20rc.pdf.

Indonesia Stock Exchange, Press Release PR Nomor 066/BEI.SPR/09-2021, https://www.idx.co.id/berita/press-release-detail/?emitenCode=1577.

Utami, D.N. (2020). "PPATK Sebut Transaksi Mencurigakan di Pasar Modal Melonjak, BEI Angkat Bicara", Bisnis.com, https://market.bisnis.com/read/20200923/7/1295774/ppatk-sebut-transaksimencurigakan-di-pasar-modal-melonjak-bei-angkat-bicara.

\section{Peraturan Perundang-Undangan}

Undang-Undang Dasar Negara Republik Indonesia Tahun 1945.

Undang-Undang Nomor 8 Tahun 1995 tentang Pasar Modal.

Undang-Undang Nomor 31 Tahun 1999 tentang Pemberantasan Tindak Pidana Korupsi.

Undang-Undang Nomor 8 Tahun 2010 tentang Pencegahan dan Pemberantasan Tindak Pidana Pencucian Uang.

Undang-Undang Nomor 9 Tahun 2013 tentang Pencegahan dan Pemberantasan Tindak Pidana Pendanaan Terorisme.

Undang-Undang Nomor 5 Tahun 2018 tentang Perubahan Atas Undang-Undang Nomor 15 Tahun 2003 tentang Penetapan Peraturan Pemerintah Pengganti Undang-Undang Nomor 1 Tahun 2002 tentang Pemberantasan Tindak Pidana Terorisme Menjadi UndangUndang.

Peraturan Pemerintah Nomor 43 Tahun 2015 tentang Pihak Pelapor dalam Pencegahan dan Pemberantasan Tindak Pidana Pencucian Uang.

Peraturan Otoritas Jasa Keuangan Nomor 22/POJK.04/2014 tentang Prinsip Mengenal Nasabah oleh Penyedia Jasa Keuangan di Pasar Modal.

Peraturan Presiden Nomor 18 Tahun 2017 tentang Tata Cara Penerimaan dan Pemberian Sumbangan oleh Organisasi Kemasyarakatan dalam Pencegahan Tindak Pidana Pendanaan Terorisme. 
Peraturan Otoritas Jasa Keuangan Nomor 23/POJK.01/2019 tentang Perubahan Atas Peraturan Otoritas Jasa Keuangan Nomor 12/POJK.01/2017 tentang Penerapan Program Anti Pencucian Uang dan Pencegahan Pendanaan Terorisme di Sektor Jasa Keuangan.

Peraturan Pusat Pelaporan dan Analisis Transaksi Keuangan Nomor 11 Tahun 2021 tentang Sistem Informasi Terduga Pendanaan Terorisme.

Kepolisian Negara Republik Indonesia. (2021).Daftar Terduga Teroris dan Organisasi Teroris Nomor: DTTOT/P-7a/149/II/RES.6.1./2021. 